\title{
СвІдОМІсть І СВІтогляД: СПРОБА ПРОБЛЕМНОГО ПІДХОДУ
}

\section{Т.П. Синько}

Останнім часом рідкий автор, який пише про проблеми кризового стану суспільства в цілому, а тим більше, якщо він намагається збагнути причини кризи духовної і світоглядної, не вживає таких понять як «ментальність», «національний характер», «національна ідея», «парадигма» тощо. Можна констатувати факт введення цих термінів в наш науковий вітчизняний обіг. Не претендуючи на всебічний аналіз такого складного явища як світоглядна свідомість (цей термін підкреслює ту обставину, що світогляд, як і свідомість не мають бути редукованими до актів знання, бо містять у собі чимало нераціональних компонентів), спробуємо простежити зміну загальної орієнтації в розумінні цього феномену та визначити деякі проблеми, що виникають при його аналізі.

Вітчизняні та зарубіжні дослідники проблеми світогляду не обходять увагою той факт, що за останні декілька років відбулася заміна сцієнтистського трактування світогляду когнітивно-ціннісною його інтерпретацією. Загальновизнаним є підхід, що заперечує картину світу, для якої характерна фіксація не зв'язку людини зі світом, а спрямованість на світ такий, який він $€$ в собі, а не для нас ${ }^{1}$.

Традиційне для радянської доби визначення світогляду як систематизованого знання про світ в цілому доповнилося блоком питань про місце людини в світі, ставлення людини до світу, системи людських ідеалів, нового розуміння специфіки свідомості (праці Є.К. Бистрицького,

\footnotetext{
${ }^{1}$ Мужик Й. К определению сущности мировоззрения // Вестник Московского университета. - 1991.—№ 2.-С. 3.
}

Актуальні проблеми духовності 
В.Л. Іванова, А.Н. Лоя, В.Г. Табачковського, Н.Ф. Тарасенко, В.І. Шинкарука та інш.).

З'явилися праці з аналізом світоглядної свідомості в плані емоційного відображення світу людиною. В них робиться спроба аналізу з точки зору різних зрізів світоглядної свідомості, при якому традиційне уявлення про те, що в певних формах світоглядної свідомості по-різному репрезентовані інтелектуальний та емоційний досвід людей поєднується зі спробами визначити місце в структурі світоглядної свідомості таких понять, як «національна ідея», «ментальність» ${ }^{2}$. Передувало цим спробам осмислення важливості мотиваційно-вольової компоненти світогляду, яка «відповідає» за формування певних настанов щодо поведінки, діяльності людини. При цьому виокремлюється частина світоглядної свідомості, яка пов'язана з настановами на практичну діяльність і отримала назву «практичної свідомості» ${ }^{3}$. Є.К.Бистрицький дав таке визначення світоглядної свідомості: «Світоглядна свідомість, а під нею на відміну від спеціально оформлених i теоретично організованих, систематичних поглядів на світ ми будемо розуміти життєво-практичні погляди та уявлення, безпосередньо вплетені в процес освоєння світу, генетично пов'язані з усім комплексом соціально-практичних наслідків розвитку математично-експеріментального природознавства - науки Нового часу, в якому ми и досі живемо» ${ }^{4}$.

Основними характеристиками «практичної свідомості» називають: фактичність, яка пов'язана із спрямованістю на конкретику людського існування в світі, предметно-смислову невизначеність, існування у вигляді умови людського буття, безпосередню дійсність. До форм «практичної свідомості» прихильники практично-духовної природи світоглядної свідомості, застосовуючи діяльнісний підхід, віднесли ті елементи реального, живого світогляду в його динаміці, які значною мірою відбивають реальний процес людської життєдіяльності: певні «програми» первісного синтезу соціального суб'єктивного досвіду переважно практичного характеру, які забезпечують елементарне існування особистості і певні «принципи», тобто ідеали, потреби, прогнози,

\footnotetext{
${ }^{2} \mathrm{O}$ днією з перших спроб визначення характерних рис української ментальності були такі праці: Шлемкевич М. Українська душа.-К., 1992; Шллемкевич М. Загублена українська людина.-К., 1994. Щодо національної ідеї, увагу привертає грунтовна робота Забужко О.С. Філософія української ідеї та європейський контекст: франківський період. - К., 1993.

${ }^{3}$ Быстрицкий Е.К. Мировоззренческая культура личности.-К., 1986.-С. 15.

${ }^{4}$ Цит. прачля.- С. 15.
} 
соціальні настанови, які безпосередньо стимулюють та спрямовують соціальну діяльність людей, певні «результати» соціальної діяльності, суб'єктивно перетворені та поціновані. Можна сказати, що пафос підходу до світоглядної свідомості з точки зору практично-духовної її природи полягає в наголошенні на вкоріненості останньої в практику, її практичній екзистенції, модальності, діяльно-практичній інтенції. Тим не менш, запропонованій термін не «прижився», і перш за все тому, що світоглядна свідомість $є$ духовним утворенням, а поняття практичного світогляду нівелює розрізняння настанови, орієнтації на діяльність та саму діяльність. Але позитивне значення полеміки навколо цієї проблеми полягає в тому, що індивідуальний світогляд людини був визнаний не тільки як результат строго раціональних теоретичних досліджень, знань. Тому він не завжди має виступати в систематизованому, теоретичному вигляді, а уявляє собою накопичення та узагальнення життєвого досвіду особистості, який імпліцитно міститься в позиціях та діях людини. Критиці був підданий сцієнтистський варіант тлумачення світоглядної свідомості як такої структури, що складається з усвідомлених елементів; неусвідомленість була визнана невід'ємною рисою світогляду.

Також було визнано функціонування світогляду принаймні на двох рівнях: особистому, індивідуальному як живого елементу свідомості, та суспільному (світогляд, для якого більш характерними $є$ теоретичність, системність, репрезентація поглядів певних соціальних груп суспільства). В ході дискусій було визнано, що редукція об'єкту світоглядної свідомості до суспільних відносин зводить діяльність особистості до рівня простого виконавця детермінованих певними пануючими у суспільстві відносинами соціальних ролей та функцій, заперечує розуміння діяльності як неперервного процесу самореалізації людини. При цьому було підкреслено, що для позбавлення об'єктивно-речового характеру соціальних ролей (які є об'єктивно заданими суб'єкту внаслідок диференціації розвинутої соціальної системи) суб'єкт професійної, ролевої діяльності повинен володіти, управляти роллю, щоби вона не формалізувала людину, не панувала нею, не переводила в одномірну площину все багатство духовного світу особистості ${ }^{5}$.

Яскравим прикладом цієї формалізації виступає бюрократизація соціального життя, причому такого плану, коли бюрократ ототожнює себе із своєю професійною функцією та відчужує від себе свою людську

\footnotetext{
${ }^{5}$ Смирнова Р.А. Мировоззрение и деятельность // Человек: философские аспекты сознания и деятельности. - Мн., 1989.- С. 94.
} 
сутність. Одночасно при цьому відбувається аналогічне відчуження щодо людей, втягнених в орбіту його професійної діяльності. На рівні соціуму негативним наслідком такого панування речового характеру соціальних ролей $\epsilon$ обмеження творчого опанування особистістю соціальними структурами, та інститутами, відносинами, а тим самимобмеження їхнього розвитку.

Очевидно, що саме світоглядна свідомість покликана долати ці обмеження. В цьому розумінні вона немов би піднята над ситуацією дії, відображуючи її смисл в перспективах діяльності не стільки повсякденної, скільки в найвідповідальніші моменти вибору смисложиттєвих орієнтацій. I тому ніякі соціальні ролі не можуть змінити того, що $є$ сенсом буття людини, забезпечує цілісність, сталість життєвих принципів, переконань, орієнтацій в ситуації постійної зміни обставин людського існування. Відмова від заідеологізованого класового підходу проявилася в переносі акценту із класових цінностей як інтегруючого чинника світогляду на усвідомлення досить високого рівня узагальнення проблем буття людини в світі і сенсу буття. За іронією долі перехід від традиційних для марксизму класових до загально значущих для людства цінностей відбувався за класичною Марксовою схемою діалектики буття та свідомості: суспільні глобальні та локальні кризові явища визначили суспільну свідомість, яка сама визначає себе кризовою.

Можна відзначити, що такі риси кризової світоглядної свідомості, як розірваність (втрата цілісності), самозаперечення власних засад, значною мірою впливають на всі рівні світогляду, в тому числі на рівень філософської рефлексії (побіжно відзначимо, що при всіх розбіжностях, рефлексія визначається як системоутворюючий компонент філософської свідомості, як самосвідомість, що формує підвалини змісту знання). Не маючи наміру докладно зупинятися на аналізі трансформації соціальних кризових процесів у кризу світоглядну, духовну, яка, на жаль, визначає нашу сучасну ситуацію, зазначимо, що на рівні філософського усвідомлення відзначені риси кризової свідомості (розірваність, заперечення власних засад є ознакою того, що відбувається зміна філософських парадигм свідомості) $)^{6}$. Не можна не погодитися з автором у тому, що змішання філософських парадигм (наприклад, змішання кантианської та феноменологічної парадигми свідомості в поглядах Гадамера, Хабермаса, Фуко, Деріди) не $є$ результатом ли-

\footnotetext{
${ }^{6}$ Однією з цікавих спроб дослідження напрямку цих змін та фундаментальних філософських орієнтацій можна назвати аналіз, який здійснюється в роботі: Молчанов В. Парадигмы сознания и структуры опыта // Логос. -1992 . - № 3 .
} 
ше індивідуальних помилок філософів, а $є$ ознакою нашої доби співіснування різноманітних, несхожих ідей та методологічних напрямків досліджень. Перспективним, на думку автора, $є$ виокремлення в структурі світоглядної свідомості світосприйняття, яке в феноменології пов'язано із ідеєю «конституювання» світу через здатність вироблення, переживання й переносу значень; феноменологічне розуміння світоставлення полягає в ототожненні його із переливанням часу, простору, тілесності, причому в кожному з цих феноменів життєвого світу так чи інакше присутній «дух епохи», завдяки цьому людина переживає свою причетність до соціуму, до культури.

Така методологічна різноманітність простежується і в роботах, присвячених проблемі ментальності, як колективної, так і індивідуальної. При цьому традиційні способи філософського осмислення цієї внутрішньої структури свідомості з позицій психоаналізу, наприклад, використовуються поряд із кількісними методами, методом контентаналізу, квантифікаційним методом тощо. Для розуміння евристичного потенціалу категорії ментальності важливими $є$ таки її характеристики: повна або часткова неусвідомленість, несистематизованість того шару свідомості, який містить соціально-психологічні настанови, способи почувати, сприймати, думати. Гуревич підкреслює її парадоксальну природу - несвідоме та неконтрольоване спотворення та спрощення ідей, продуктів духовної культури, що функціонують у суспільстві ${ }^{7}$.

Як специфічну рису існування ментальних структур на рівні світоглядної свідомості можна відмітити те, що виникаючи на базі засвоєння деякими соціальними групами продуктів духовної культури суспільства у вигляді певних настанов та мотивацій, ментальність дещо спотворює зміст засвоюваних ідей. А опісля в такому зміненому вигляді ідеї повертаються у суспільну свідомість і продовжують там функціонувати, закріплюючи та формуючи ментальні структури. Таким чином, виникає певне замкнене коло взаємоформування та взаємообумовленості ментальних та рефлексивних структур свідомості. Саме у такому предметному полі дослідження українських науковців опинився блок питань про те, які саме риси національної ментальності і характеру (інтровертність, кордоцентризм, естетизм, антеїзм-зв'язок з землею, природою, космосом, екзистенціальність «внутрішньої людини»), позначаються на здобутках філософії та модусі національ-

\footnotetext{
${ }^{7}$ Гуревич А.Я. Смерть как проблема исторической антропологии: о новом направлении в зарубежной историографии // Одиссей. - 1989.-С. 132.
} 
ної ідеї? I ширше - як вони формують неповторну єдність збірної індивідуальності? Ця проблема пов'язана з тим, що специфіку націй висвітлює конкретне співставлення, культура розвивається на стику і в діалозі з іншими. Українська ж нація виникла на перетині західних, східних і південних впливів, на плацдармі їхньої зустрічі і взаємодії. Це призвело до багаторазового повторення ситуації напруженого вибору на роздоріжжі, непередбачуваності історичної долі, незакріпленості раціональних структур - натомість до вибухово-інтенсивної творчості окремих речників нашого народу.

Прикладом застосування методологічних засад психоаналізу та герменевтичного підходу на тлі соціокультурного контексту є дослідження національної ідеї та ментальності в роботах О.Забужко М. Савельєвої ${ }^{9}$ та інш. Специфічною рисою української культури Забужко вважає переосмислення конкретно історичної долі нації як висліду її власної волі дотримуватися цього задуму або відхилятися від нього. Звідси у філософії української ідеї з'являється мотив «історіїкари», «історії-спокути». Історія мислиться тут як свого роду «антиісторія» (підмінна, вкрадена історія - мотив «пропалої грамоти» у Гоголя), за якої нація втрачає самочинність, перестаючи бути суб'єктом власної волі, і тим прирікає себе на фактичне «не-життя», «життясон», «похованість живцем» (архетипальні для новітньої української свідомості образи - від «закопаного скарбу» Гоголя до Того, що в скелі сидить, у Лесі Українки). Забужко аналізуе категорію часу в антиісторії (позачасся-безподієвість), співвідношення дійсного і можливого в свідомості, обтяженій комплексом антиісторизму («мрійництво» як мислення в умовному способі), а також початки рефлексії над цими явищами в українській філософській культурі перших десятиліть XX сторіччя. До архетипальних структур національної міфології також звертається Н. Хамітов. На його думку, в архетипі здійснюється взаємовплив міфологічних і символічних моментів, що дає йому можливість бути «онтологічним атомом» національної ідеї, включеним до національного буття ${ }^{10}$.

М.Савельєва відзначила такі риси української ментальності, як

\footnotetext{
8 Забужко О. Філософія і культурна притомність нації // Хроніки від Фортінбраса. -К., 1999; Забужко О. Шевченків міф України. Спроба філософського аналізу. - К.,1997.

${ }^{9}$ Савелъева M. Надкультурное: Очерки метатеории сознания.-K., 1997; Caвелвева М. Введение в метатеорию сознания. - К., 2002.

${ }^{10}$ Хамітов $Н$. Національна ідея в духовній культурі України // Філос. і соціол. думка. - 1993. - № 11. - С. 242.
} 
прагнення до великого і безмежного, відважне зіткнення контроверсій, на рівні філософських понять це- «соборність», «серце» (Сковорода, Юркевич), «усамітнення» (Гоголь), «мир» (Куліш), що вкупі складає національний варіант Живої Етики. На переконання Савельєвої, українець - «культуролог», тож йому дуже важко пристосуватися до технічно глобалізованої цивілізації.

Багатьма науковцями з'ясування онтологічних підстав національної ідеї, їі опертя в національному бутті, механізмів продукування своєрідного світобачення і життєтворчості пов'язується з мовою, фольклором, традиціями, ментальністю, характером, пам'яттю, чуттєвістю та іншими компонентами культури.

В. Мовчан виділяє три етапи розвитку національної ідеї: а) безпосередньо-чуттєвий, розчинення в середовищі; б) логічного визначення й усвідомлення; в) повернення в народ як своєї, вистражданої думки й надії ${ }^{11}$.

Такою особливою рисою національна ідея постає як феномен культури на відміну від ідеології, що їі нав'язують згори. Це не означає ізольованості національної ідеї від ідеології, вона може виражати: конкретно-політичні завдання нації, закоріненість у національний міф, месіанські претензії. Як специфічну рису можна відзначити здатність до «опору» ідеологічній експансії ментальних настанов. На думку багатьох дослідників цьому сприяє те, що останні існують в органічній формі категорій культури та архетипальних складових світогляду: землі, матері, хати, батьківщини тощо.

Серед негативних рис української ментальності зазначена її маргінальність. На користь тези про маргінальну сутність ментальності України говорить визначення українців як спільноти некласичного типу, якій властиві: існування між різними полюсами, на лінії боротьби, на грані ризику; нестабільність і динамізм; багатодержавність на етнічній території; поліідеологічність; потяг до свободи «від» (бунтарство), а не до свободи «для» (творення).

Така наявність деструктивних тенденцій ставить під знак запитання саме існування України як цілісності. Відповіддю на це проблемне питання постає позиція, згідно з якою маргінальна ситуація української культури зовсім не $є$ проміжною зоною «бермудського трикутника», де щезають класичні риси, прищеплені сусідами, натомість маємо самобутність, що синтезувала соціокультурні впливи сусідніх

\footnotetext{
${ }^{11}$ Мовчан B. Національна ідея в духовній культурі України // Філос. і соціол. думка. - 1993. - № 11.- С. 248.
} 
країн та народів. Отже, позиція України не стільки «між», скільки «і там, і там», що формує своєрідну культуру внаслідок «інтерференції хвиль». Однак залишаються проблемою вольові інтенції нації щодо самого життя. Представляється, що в рамках «маргінального» підходу розв'язати цю проблему неможливо. Тому нагальною потребою $\epsilon$ створення моделі розвитку національної ідеї та ментальності в рамках самоідентифікаційного підходу, враховуючи такі засадничі характеристики нашої культури, як багатоцентровість, плюралізм, міжпарадігмальність тощо.

Одним з системоутворюючих кризових чинників в культурі $є$ глобальна уніфікація, що загрожує автохтонній природності і самобутності етносів, а отже обертається аморальністю, деградацією людини, культури, суспільства.

Протиставлення і відрив двох гілок (рівнів) сучасного буття є непродуктивним, отже, слід шукати взаємодоповнення природного та індустріального начал. Яскравим прикладом такого синтетичного поєднання спромоглася стати японська культура. Таким чином, актуальною проблемою для самого існування української культури залишається здатність їі (а також таких важливих складових національної свідомості, як національна ідея та ментальність) до синтезу соціокультурних інновацій і відтворення власних самобутніх підвалин. Не в останню чергу сприяти цьому процесу має філософський аналіз проблем культури, свідомості, духовності людини, здійснений на засадах поєднання теоретичної та практичної філософії, класичної трансцендентальної методології та посткласичних підходів. 